\begin{abstract}
STUDIEs were carried out to evaluate the impact of a high-fat dietary regimen on aortic wall thickness, peripheral blood leukocyte profile, and plasma cholesterol and triglyceride levels in the mast celldeficient $S 1 / S^{d}$ mouse. The results demonstrated that the mean aortic wall thickness of $S 1 / S^{d}$ mice was significantly higher than their normal littermates, and were increased in both genotypes after a 17-day high-fat regimen. In comparison with normal littermates, $\mathrm{Sl} / \mathrm{Sl}^{\mathrm{d}}$ genotypes had elevated levels of plasma triglycerides with normal levels of plasma cholesterol, and the high-fat diet markedly lowered the triglyceride levels. Total peripheral blood leukocytes, the monocyte and granulocyte counts, and hemoglobin levels were significantly lower in $\mathrm{Sl} / \mathrm{Sl}^{\mathrm{d}}$ mice, although the number of lymphocytes, eosinophils and basophils were the same in both genotypes. Interestingly, the high-fat diet regimen elevated leukocyte counts and the number of monocytes and granulocytes in $\mathrm{Sl} / \mathrm{Sl}^{\mathrm{d}}{ }^{\mathrm{m}}$ mice.
\end{abstract}

Key words: High-fat diet, Stem cell factor deficiency, Mast cell deficiency, Intima media thickness, Hypertriglyceridemia

\section{Deranged aortic intima-media thickness, plasma triglycerides and granulopoiesis in $\mathrm{SI} / \mathrm{SI}^{d}$ mice}

\author{
Kottarappat N. Dileepan ${ }^{1, C A}$, Thomas P. Johnston ${ }^{2}$, \\ Yuai $\mathrm{Li}^{1}$, Ossama Tawfik $^{3}$ and \\ Daniel J. Stechschulte
}

${ }^{1}$ Division of Allergy, Clinical Immunology and Rheumatology, Department of Medicine, and ${ }^{3}$ Department of Pathology and Laboratory Medicine, University of Kansas Medical Center, Kansas City, KS 66160, USA; ${ }^{2}$ Division of Pharmaceutical Sciences, School of Pharmacy, University of Missouri-Kansas City, MO 64110, USA

\footnotetext{
${ }^{\mathrm{CA}}$ Corresponding Author

Tel: + 19135883818

Fax: +19135883987

E-mail: kdileepan@kumc.edu
}

\section{Introduction}

The pathogenesis of atherosclerosis shares many features of the inflammatory response and is characterized by endothelial cell activation, infiltration of inflammatory cells, accumulation of macrophages and mast cells, and proliferation of smooth muscle cells. ${ }^{1,2}$ Mast cells are important cells of the innate immune system and play a role in mediating the pathophysiology of many inflammatory diseases. Mast cells are strategically located in the vessel wall and release many inflammatory mediators upon their activation. These include histamine, prostaglandin $\mathrm{D}_{2}$, leukotrienes, heparin, and a variety of cytokines, and proteases. ${ }^{3-7}$ Although mast cells are primarily known for their role in the development of hypersensitivity reactions, strong evidence implicates this cell type in the progression of atherosclerosis. The presence of an increased number of mast cells in atherosclerotic lesions, ${ }^{8-12}$ atheromas, ${ }^{13}$ and in the adventitia of coronary arteries with plaques ${ }^{14,15}$ supports this concept. In addition, thrombus formation is associated with an increase in the number of mast cells in the arterial wall. ${ }^{8}$ The participation of mast cells in vascular physiology is further supported by the localization of mast cell granules within endothelial cells in vivo ${ }^{16}$ and by the ability of mast cell granules to induce proliferation of human microvascular endothelial cells. ${ }^{17}$ The localization of mast cells in the human heart ${ }^{12}$ and the recognition of mast cell chymase as a factor in the generation of angiotensin $\mathrm{II}^{7,18}$ support the role of mast cells in both myocardial and vascular function.

Disorders in lipid metabolism are major risk factors for the development of atherosclerosis. According to this hypothesis, modified low-density lipoprotein (LDL) is taken up by endothelial cells, macrophages and smooth muscle cells. In the subendothelial space, modified LDL can act as a chemoattractant for monocytes that adhere to the endothelium, migrate into subendothelial space and become macrophages that transform into foam cells by uptake of altered LDL. Mast cell granule proteases have been shown to modify LDL and enhance their uptake by macrophages with transformation to foam cells, ${ }^{13,19}$ suggesting a role for the mast cell in lipidrelated atherosclerosis.

The Steel-Dickie Sl/Sl ${ }^{\mathrm{d}}$ mouse is mast cell deficient due to a mutation by which the transmembrane and cytoplasmic domains of stem cell factor (SCF) are deleted. It is well recognized that SCF is essential for mast cell differentiation and maturation, as well as for granulopoiesis. ${ }^{20,21}$ The present study was designed to determine the relative atherogenic potential of a high-fat regimen in normal and $\mathrm{Sl} / \mathrm{Sl}^{\mathrm{d}}$ mice with the focus of understanding the role of mast cells in 
atherosclerosis. The results of the present study demonstrate that the aortic wall thickness of mast cell-deficient $\mathrm{Sl} / \mathrm{Sl}^{\mathrm{d}}$ mice is significantly higher than normal controls, when adjusted for body weight, and was increased in both genotypes after the high-fat regimen. Furthermore, in comparison with normal littermates, mast cell-deficient genotypes have elevated levels of plasma triglycerides without altered levels of plasma cholesterol. The results revealed that the atherogenic high-fat diet increased the aortic wall thickness, increased plasma cholesterol and lowered triglyceride levels in both $\mathrm{Sl} / \mathrm{Sl}^{\mathrm{d}}$ and normal mice. In addition, the mast cell-deficient mice partially corrected their defective erythropoiesis, and both $\mathrm{Sl} / \mathrm{Sl}^{\mathrm{d}}$ and their normal littermates demonstrated increased granulopoises after the high-fat regimen.

\section{Material and methods}

\section{Animals and diet}

The 5-week-old to 6-week-old female $\mathrm{Sl} / \mathrm{Sl}^{\mathrm{d}}$ mice and the normal littermates used in the study were of C57BL/6 lineage and were obtained from Jackson Laboratories (Bar Harbor, ME, USA). The control diet was Purina Breeder Chow whereas the highfat diet was prepared by mixing a diet containing $30 \%$ cocoa butter, $5 \%$ cholesterol, $2 \%$ sodium cholate, $30 \%$ casein, 5\% aphacel, $4 \%$ vitamin mixture, 6.5\% sucrose, $6.5 \%$ dextrin and $0.5 \%$ cholic acid with Purina Breeder Chow in a ratio of $1: 3$ parts $(\mathrm{w} / \mathrm{w})$, respectively, and then pelleted (Harlan-Teklad, Madison, WI, USA). Diagnostic enzyme kits for determination of total plasma cholesterol and triglycerides were obtained from Sigma (St Louis, MO, USA).

\section{Animal treatment}

Sixteen $\mathrm{Sl} / \mathrm{Sl}^{\mathrm{d}}$ mast cell-deficient mice and $16 \mathrm{C} 57 \mathrm{BL} /$ 6 mice were used in this study. Eight animals from each genotype were randomized into each of the two dietary regimens, 'normal diet' and 'high-fat diet'. The animals in the 'normal diet' group were fed the standard mouse chow while those in the 'high-fat diet' were given a high-fat, high-cholesterol diet for 17 weeks. The animals were housed in a temperature-controlled $\left(22^{\circ} \mathrm{C}\right)$ facility throughout the duration of the experiment, and were provided free access to food and water. The initial and final body weights of all animals were recorded. At the end of the experimental protocol, all animals were euthanized by Halothane inhalation prior to the harvest of tissues. All procedures employed in this study were in accordance with the institution's guidelines for care and use of laboratory animals and the protocols were approved by Laboratory Animal Research Committee of the University of Kansas Medical Center.

\section{Blood and tissue sampling}

Seventeen weeks after the start of the study animals were anesthetized with metaphane and blood samples were collected from each mouse using the retroorbital sampling technique into heparinized capillary tubes. In addition, blood smears were prepared for total and differential counts of leukocytes.

\section{Plasma lipid analysis}

Blood samples collected in heparinized capillary tubes were immediately centrifuged, the plasma removed, and were frozen at $-80^{\circ} \mathrm{C}$ until the time of analysis. Plasma samples were assayed for total cholesterol and triglycerides using standard enzymatic assay kits according to the manufacturer's instructions. The concentrations of cholesterol in the serum were measured by a colorimetric assay. ${ }^{22}$ Triglyceride levels in the plasma were assayed with ultraviolet detection at $340 \mathrm{~nm}$ as described elsewhere. ${ }^{23}$ All plasma lipid analyses were performed in duplicate.

\section{Histology}

After exsanguination, the heart with $1-1.5 \mathrm{~cm}$ of ascending thoracic aorta was dissected and rinsed with cold phosphate-buffered saline and placed in $10 \%$ neutral buffered formalin until sectioning for microscopic analysis. Aortic specimens were serially sectioned into three or four rings and embedded entirely in tissue blocks for hematoxylin and eosin ( $\mathrm{H} \& \mathrm{E})$ staining. Histologic sections were then reviewed by one person (O.T.) and scanned by a computer assisted imaging device (CAS-200 Cell Analysis System; Bacus Laboratory, Chicago, IL, USA) for measurement of the vessel wall thickness. The mean value of the vessel wall thickness from the endothelial surface to the adventitia was recorded from 10 different locations spanning the entire crosssection.

\section{Data analysis}

The mean values of aortic wall thickness were first normalized for overall body weight, since it has been shown that larger mice generally exhibit larger vessel wall thickness. Mean values of the aortic wall thickness were compared using a standard Student $t$-test with two independent samples using a twotailed comparison. Statistical significance was assumed at $p<5 \%$. Comparisons were made between $\mathrm{Sl} / \mathrm{Sl}^{\mathrm{d}}$ and their normal littermates $(+/+)$ mice while holding the diet type constant (i.e. high-fat and 
normal chow), and between the high-fat diet and the control diet while holding the mouse strain constant (i.e. mast cell-deficient and C57BL/6 mice) (Table 1). Plasma concentrations of total cholesterol and triglycerides were analyzed in a similar manner (Fig. 1). A one-way analysis of variance was utilized to compare mean values of the various hematological parameters presented in Table 2. If a significant value of $p$ associated with the F-value was obtained, post boc testing by the method of Scheffe was used to identify significantly different mean values.

\section{Results}

The mean body weight of $\mathrm{Sl} / \mathrm{Sl}^{\mathrm{d}}$ mice was significantly lower than that of their age-matched normal controls at the beginning and end of the experiment irrespective of the type of diet consumed during the course of the experiment. The mean body weight of the normal mice that were fed the standard chow diet was $29.7 \pm 2.51 \mathrm{~g}(n=8)$ compared with $21.0 \pm 5.30 \mathrm{~g}$ ( $n=5$; three mice died) for mast cell-deficient mice fed the same diet. Similarly, the mean body weight of the normal mice fed a high-fat diet was $27.2 \pm 1.28 \mathrm{~g}$ $(n=8)$ compared with $20.8 \pm 4.50 \mathrm{~g}(n=8)$ for mast cell-deficient mice fed the same diet. In general, mast cell deficient mice weighed approximately $7-8 \mathrm{~g}$ less than the corresponding control animals. The weight gain during the 17 weeks of treatment was the same for both $\mathrm{Sl} / \mathrm{Sl}^{\mathrm{d}}$ and normal littermates irrespective of the diet they consumed.

\section{Plasma lipids}

The total plasma cholesterol concentrations for normal and $\mathrm{Sl} / \mathrm{Sl}^{\mathrm{d}}$ mice fed a control diet or highfat diet are given in Fig. 1. As is evident there was no difference in plasma cholesterol levels between the normal and $\mathrm{Sl} / \mathrm{Sl}^{\mathrm{d}}$ mice $(98 \pm 3 \mathrm{mg} / \mathrm{dl}$ and $102 \pm 3 \mathrm{mg} / \mathrm{dl}$, respectively). The 17 -week high-fat regimen resulted in a significant increase in plasma

Table 1. Aortic intima-media thickness in normal $(+/+)$ and $\mathrm{SI} / \mathrm{SI}^{\mathrm{d}}$ mice maintained on a normal diet or a highfat diet

\begin{tabular}{lccc}
\hline Genotype & Diet & $\begin{array}{c}\text { Aortic intima } \\
\text { media-thickness } \\
(\mu \mathrm{m})\end{array}$ & $\begin{array}{c}\text { Aortic-intima } \\
\text { media thickness } \\
(\mu \mathrm{m} / \mathrm{g} \text { of body } \\
\text { weight })\end{array}$ \\
\hline$+/+$ & Normal & $54.5 \pm 4.8(n=8)^{\mathrm{a}}$ & $1.84 \pm 0.16(n=8)$ \\
$+/+$ & High-fat & $58.0 \pm 6.1(n=8)$ & $2.15 \pm 0.16(n=8)^{\mathrm{b}}$ \\
$\mathrm{SI} /\left.\mathrm{SI}\right|^{\mathrm{d}}$ & Normal & $49.0 \pm 4.1(n=5)$ & $2.40 \pm 0.41(n=5)^{\mathrm{b}}$ \\
$\mathrm{SI} / \mathrm{SI}{ }^{\mathrm{d}}$ & High-fat & $61.0 \pm 6.8(n=8)$ & $2.83 \pm 0.35(n=8)^{\mathrm{c}, \mathrm{d}}$ \\
\hline
\end{tabular}

${ }^{\text {a } M e a n}$ value \pm standard deviation (number of animals evaluated).

bSignificantly $(p<0.05)$ greater than controls eating a normal diet.

'Signifcantly $(p<0.05)$ greater than controls eating a high-fat diet.

${ }^{d}$ Significantly $(p<0.05)$ greater than mast cell-deficient $\left(\mathrm{SI} / \mathrm{SI}{ }^{d}\right)$ mice eating a normal diet.

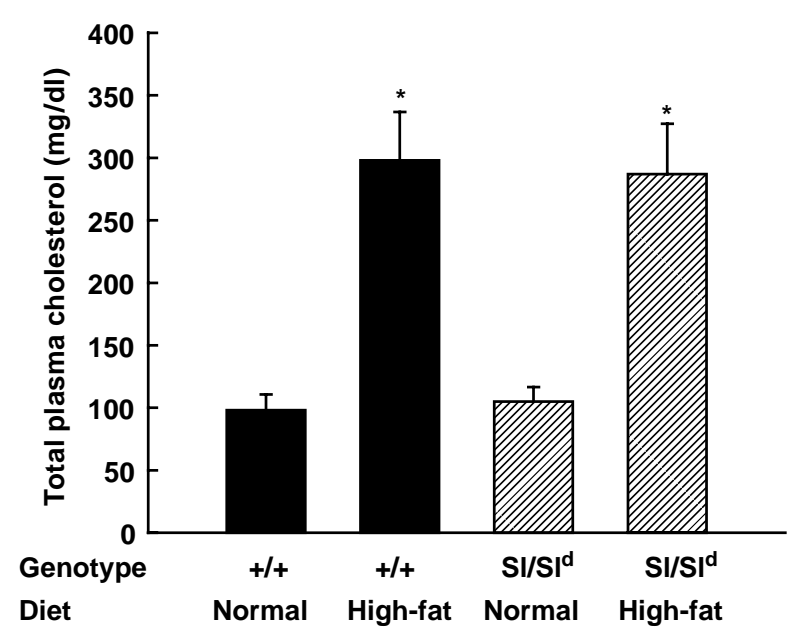

FIG. 1. Plasma cholesterol levels in normal $+/+$ (solid bars) and mast cell-deficient $\mathrm{SI} / \mathrm{SI}^{\mathrm{d}}$ (hatched bars) mice maintained on a normal diet or a high-fat diet. The results are the mean \pm standard deviation of 10 animals per group except for the $\mathrm{SI} / \mathrm{SI}^{d}$ group fed a normal diet, which had five animals. * Significant $(p<0.05)$ increase in the mean value within each strain when compared with mice eating a normal diet for that strain.

cholesterol levels in both normal $(295 \pm 5 \mathrm{mg} / \mathrm{dl})$ and the mast cell-deficient $\mathrm{Sl} / \mathrm{Sl}^{\mathrm{d}}$ mice $(287 \pm 7 \mathrm{mg} / \mathrm{dl})$. The magnitude of the increase of total plasma cholesterol was the same in both genotypes of mice, suggesting that mast cells do not play a role in plasma cholesterol homeostasis.

In comparison with the normal littermates, $\mathrm{Sl} / \mathrm{Sl}^{\mathrm{d}}$ mice presented higher levels of plasma triglycerides (Fig. 2). Consumption of the high-fat diet reduced plasma triglyceride levels in both normal and mast cell-deficient mice. Despite the presence of naturally elevated plasma triglyceride levels in $\mathrm{Sl} / \mathrm{Sl}$ mice, feeding a high-fat diet was found to decrease these levels (Fig. 2).

\section{Aortic intima-media thickness}

Mast cells are important constituents of the vasculature and may participate in the development and maintenance of vascular structure. Therefore, the deficiency of mast cells may lead to structural derangements of the vessel wall. To evaluate this possibility and examine the influence of an atherogenic diet on the vessel wall, aortic specimens were serially sectioned into three or four rings and embedded in tissue blocks for $\mathrm{H} \& \mathrm{E}$ staining. The aortic rings stained with $\mathrm{H}$ \& $\mathrm{E}$ stains from a representative control mouse are shown in Fig. 3. Histological sections were then reviewed and scanned by a computer-assisted imaging device for measurement of the vessel wall thickness (Table 1). The mean value of the vessel wall thickness from the endothelial surface to the adventitia was recorded from 10 different locations spanning the entire crosssection. When normalized for the body weights, 
Table 2. Peripheral blood leukocyte counts and hemoglobin levels in normal and SI/SI/ ${ }^{d}$ mice maintained on a normal diet or a high-fat diet

\begin{tabular}{lcccccccc}
\hline Genotype & Diet & $\begin{array}{c}\text { Leukocytes } \\
(/ \mu \mathrm{l})\end{array}$ & $\begin{array}{c}\text { Neutrophils } \\
(\%)\end{array}$ & $\begin{array}{c}\text { Lymphocytes } \\
(\%)\end{array}$ & $\begin{array}{c}\text { Monocytes } \\
(\%)\end{array}$ & $\begin{array}{c}\text { Eosinophils } \\
(\%)\end{array}$ & $\begin{array}{c}\text { Basophils } \\
(\%)\end{array}$ & $\begin{array}{c}\text { Hemoglobin } \\
(\mathrm{g} / \mathrm{dl})\end{array}$ \\
\hline$+/+$ & Normal & $6110 \pm 1050$ & $5.9 \pm 0.9$ & $86.5 \pm 1.4$ & $7.6 \pm 1.5$ & $0.7 \pm 0.01$ & $0.2 \pm 0.01$ & $15.5 \pm 0.4^{\mathrm{c}}$ \\
$+/+$ & High-fat & $7480 \pm 1300$ & $10.4 \pm 4.8^{\mathrm{a}, \mathrm{b}}$ & $80.5 \pm 7.1$ & $9.1 \pm 2.8$ & $0.7 \pm 0.02$ & $0.2 \pm 0.01$ & $14.1 \pm 0.6^{\mathrm{b}}$ \\
$\mathrm{SI}^{\mathrm{SS}}{ }^{\mathrm{d}}$ & Normal & $4700 \pm 1300$ & $2.0 \pm 1.0$ & $93.0 \pm 4.9$ & $4.9 \pm 3.9$ & $0.7 \pm 0.01$ & $0.2 \pm 0.02$ & $6.4 \pm 3.7^{\mathrm{b}}$ \\
$\mathrm{SI}^{\mathrm{SS}}{ }^{\mathrm{d}}$ & High-fat & $6310 \pm 1900$ & $5.9 \pm 1.9$ & $86.3 \pm 4.6$ & $7.9 \pm 2.8$ & $0.7 \pm 0.03$ & $0.2 \pm 0.01$ & $8.4 \pm 1.5$ \\
\hline
\end{tabular}

a Significant $(p<0.05)$ difference compared with wild-type mice consuming a normal diet.

b Significant $(p<0.05)$ difference compared with $\mathrm{SI} / \mathrm{SI}$ mice consuming a high-fat, high-cholesterol diet containing cholate.

${ }^{\mathrm{c}}$ Significant $(p<0.05)$ difference compared with $\mathrm{SI} / \mathrm{SI}$ mice consuming a normal diet.

the mean aortic intima-media thickness was higher for $\mathrm{Sl} / \mathrm{Sl}^{\mathrm{d}}$ mice than for their normal littermates (Table 1). Consumption of the high-fat diet resulted in an increase in aortic intima-media thickness in both normal and $\mathrm{Sl} / \mathrm{Sl}^{\mathrm{d}}$ mice. However, the increase in aortic intima-media thickness in $\mathrm{Sl} / \mathrm{Sl}^{\mathrm{d}}$ mice fed the high-fat diet was not different when compared with those fed a normal chow diet.

\section{Peripheral blood leukocyte counts}

The total peripheral blood leukocyte counts and hemoglobin levels were markedly lower in mast cell-deficient $\mathrm{Sl} / \mathrm{Sl}^{\mathrm{d}}$ mice than their normal littermates (Table 2). The differential counts of the peripheral blood smear revealed no apparent difference in the number of lymphocytes, eosinophils and basophils between the two genotypes. However, the number of monocytes and granulocytes were lower in $\mathrm{Sl} / \mathrm{Sl}^{\mathrm{d}}$ mice. Interestingly, the consumption of a high-fat diet normalized leukocyte counts, raised hemoglobin levels, and increased the number of granulocytes and monocytes in $\mathrm{Sl} / \mathrm{Sl}^{\mathrm{d}}$ mice.

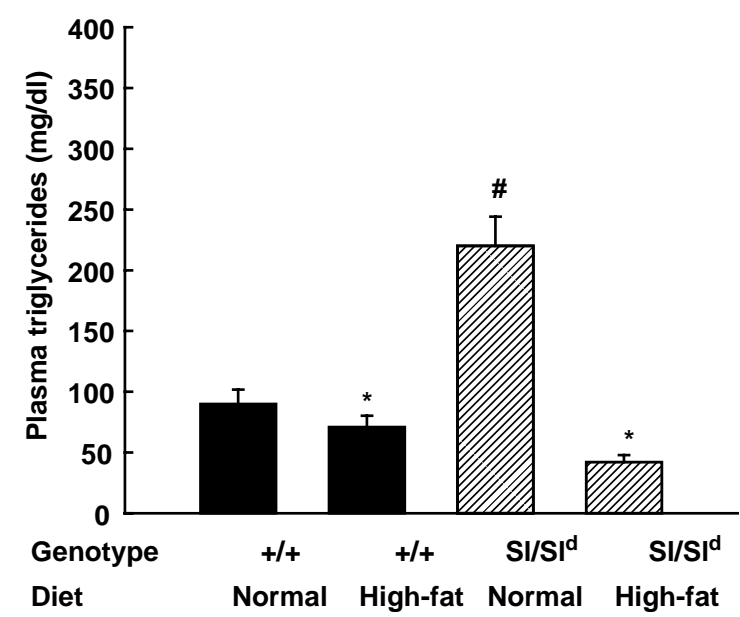

FIG. 2. Plasma triglyceride levels in normal $(+/+$, solid bars $)$ and $\mathrm{SI} / \mathrm{SI}^{\mathrm{d}}$ (hatched bars) mice maintained on a normal diet or a high-fat diet. The results are the mean \pm standard deviation of 10 animals per group except for the $\mathrm{SI} / \mathrm{SI}^{\mathrm{d}}$ group fed a normal diet, which had five animals. * Significant $(p<$ $0.05)$ decrease in the mean value within each strain when compared with mice eating a normal diet for that strain. \# Significant $(p<0.05)$ increase in the mean value compared with $+/+$ mice consuming a normal diet.

\section{Discussion}

The results presented in this report demonstrate that the aortic wall thickness of mast cell-deficient $\mathrm{Sl} / \mathrm{Sl}^{\mathrm{d}}$ mice is 30\% higher than their normal littermates, when adjusted for body weights. The high-fat regimen increased the aortic wall thickness in both the normal and $\mathrm{Sl} / \mathrm{Sl}^{\mathrm{d}}$ mice by $17 \%$ and $18 \%$, respectively, suggesting that neither stem cell factor deficiency or mast cell deficiency resulted in enhanced changes in vascular wall structure after a 17-week atherogenic high-fat regimen. An intriguing finding of this study is that the mast cell-deficient genotypes have elevated levels of plasma triglycerides and normal levels of levels of plasma cholesterol. The total peripheral blood leukocyte counts and hemoglobin levels were significantly lower in mast cell-deficient mice than their normal littermates. The differential counts of the peripheral blood smear revealed no apparent difference in the number of lymphocytes, eosinophils and basophils between the two genotypes of mice. However, the number of monocytes and granulocytes were lower in $\mathrm{Sl} / \mathrm{Sl}^{\mathrm{d}}$ mice. Interestingly, the consumption of a high-fat diet resulted in normalization of total leukocyte counts as well as monocyte and granulocyte counts in $\mathrm{Sl} / \mathrm{Sl}^{\mathrm{d}}$ mice.

It is well recognized that vascular structures are typically well endowed with mast cells and they are recruited to vessels undergoing atherosclerotic changes. ${ }^{14,15}$ It is not known whether mast cells are recruited to vascular structures for the physiologic maintenance of vascular integrity or to participate in a pathologic event. The presence of mast cells in atherosclerotic lesions could be important because they release large amounts of chemotactic agents, inflammatory molecules, histamine and proteases, all of which are known to participate in endothelial cell activation $^{24-27}$ and possibly the maintenance of vascular integrity. Numerous studies have demonstrated the role of mast cell proteases in mediating extracellular matrix degradation through activation and secretion of matrix metalloproteinases (MMPs). ${ }^{28}$ On a weight and molar basis, enzymatically active neutral proteases are the major exocytosed protein constituents from activated mast cells. ${ }^{4}$ Tryptases, chymases, and carboxypeptidase A, in various com- 


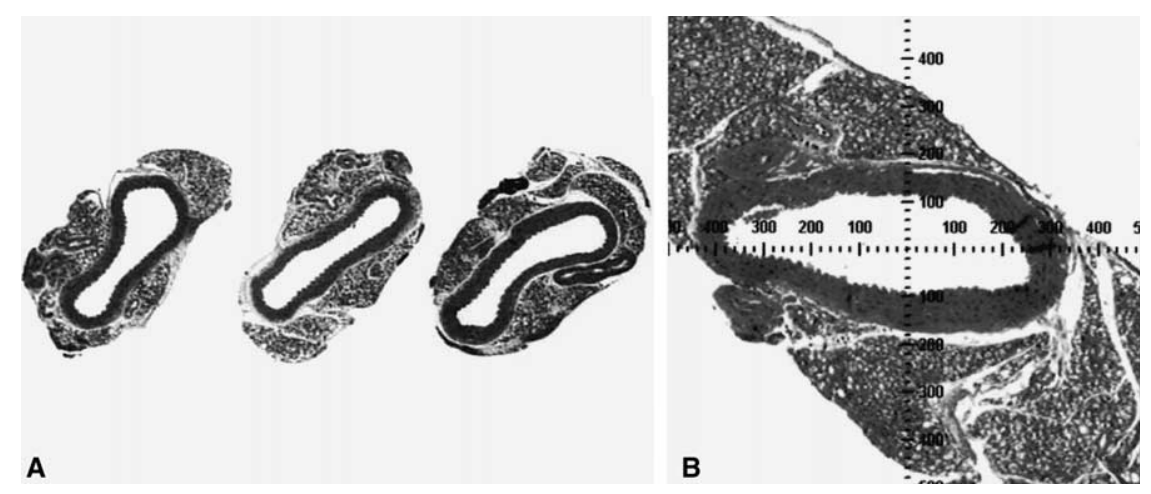

FIG. 3. Images of aortic rings from a representative normal $(+/+)$ mouse depicting the technique used for the determination of the intima media thickness. Aortic specimens were serially sectioned into three or four rings $(A)$ and embedded entirely in tissue blocks for H \& E staining. Histological sections were reviewed and scanned by a computer-assisted imaging device for measurement of the vessel wall thickness. The mean value of the vessel wall thickness from the endothelial surface to the adventitia was recorded from 10 different locations spanning the entire cross-section. The cross lines (B) depict the measurement of the vessel wall thickness in microns. Magnification $\times 200$.

binations, represent the three major classes of proteases stored in the granules of mast cells. Mast cell tryptase and chymase are capable of activating the latent forms of MMP- $2,{ }^{29}$ MMP- $9,{ }^{30}$ collagenase and stromelysin. ${ }^{31}$ Furthermore, stem cell factor has been shown to modulate MMP-9 secretion by mast cells. $^{32,33}$ Thus, a simple explanation for the increased aortic wall thickness in $\mathrm{Sl} / \mathrm{Sl}^{\mathrm{d}}$ mice may be mast cell deficiency-related absence of one or more of these metalloproteinases that are required for the maintenance and remodeling of vascular structure.

It is of interest that the $\mathrm{Sl} / \mathrm{Sl}^{\mathrm{d}}$ mice presented elevated levels of plasma triglycerides and increased aortic wall thickness. Hatanaka et al.$^{34}$ demonstrated that approximately $70 \%$ of mast cell-deficient $\mathrm{W} / \mathrm{W}^{\mathrm{v}}$ mice exhibited hypertriglyceridemia combined with hypercholesterolemia. Fig. 2 demonstrates that the $\mathrm{Sl} /$ $\mathrm{Sl}^{\mathrm{d}}$ mice fed a normal diet had a greater than two-fold increase in plasma triglyceride levels compared with normal mice fed the same diet. The plasma cholesterol levels (Fig. 1) were comparable in normal and $\mathrm{Sl} / \mathrm{Sl}^{\mathrm{d}}$ mice but were elevated to the same magnitude in both genotypes after the high-fat dietary regimen. Recent reports suggest the involvement of mast cell proteases in cardiovascular disease. The localization of mast cells in the human heart ${ }^{12}$ and the recognition of mast cell chymase as a major pathway for the generation of angiotensin $\mathrm{II}^{7,18}$ support the role of mast cells in both myocardial and vascular function. It is possible that mast cell proteases play a role in the clearance of plasma lipids via macrophage uptake and degradation. To this effect mast cell chymase and carboxypeptidase A are known to degrade LDL. ${ }^{13,19}$ Again, it is of interest that the serum cholesterol levels were unaltered in the mast cell-deficient $\mathrm{Sl} / \mathrm{Sl}^{\mathrm{d}}$ genotypes. This finding together with the increased triglyceride levels in $\mathrm{Sl} / \mathrm{Sl}^{\mathrm{d}}$ mice suggest that deficiency of mast cell proteases, which are known to degrade and augment triglyceride uptake by macrophages, may be responsible for the hypertriglycer- idimia. The lipoprotein lipase and hepatic triacylglycerol lipase in the plasma following an injection of heparin were markedly lower in mast cell-deficient mice compared with normal mice, although the activity of both lipoprotein lipase in the heart and adipose tissue and hepatic triacylglycerol lipase in the liver were not decreased. ${ }^{34}$ These authors concluded that mast cell-deficient mice have a genetic defect in one or more of the following: (1) secretion of both lipases from their synthesizing cells, (2) transport to the endothelium, and/or (3) anchoring to the endothelial surface.

It is intriguing that for both normal and mast celldeficient mice, ingestion of a high-fat, high-cholesterol diet containing 5\% cholate (cholic acid) resulted in a significant decrease in the plasma triglyceride levels. This is consistent with the findings of Ikemoto et al. ${ }^{35}$ who demonstrated that blood triglyceride concentrations decreased significantly $(p<0.001)$ when normal C57BL/6 mice were allowed to consume a high-fat, high-cholesterol diet containing cholate compared with control animals that ingested a standard low-fat chow. Blood triglyceride concentrations decreased from approximately $90 \mathrm{mg} / \mathrm{dl}$ to 15 $\mathrm{mg} / \mathrm{dl}$ when the mice consumed the diet for 9 weeks. ${ }^{35}$ This trend was observed in our study as well (Fig. 2). Moreover, this may potentially be the reason that the mast cell-deficient mice fed a high-fat, high-cholesterol diet containing cholate demonstrated a significant decrease in their plasma triglyceride compared with mast cell-deficient mice that were allowed to consume a normal low-fat chow diet (Fig. 2).

The mechanism by which the high-fat diet induced granulopoeisis and erythropoeisis in $\mathrm{Sl} / \mathrm{Sl}^{\mathrm{d}}$ mice is not known. $\mathrm{Sl} / \mathrm{Sl}^{\mathrm{d}}$ mast cell-deficient mice present an abnormal microenvironment for hematopoeisis due to defective production of stem cell factor by bone marrow stromal cells. ${ }^{36,37}$ Previous studies have documented reduced numbers of natural killer cells, 
osteoclasts and basophils in microophtalmic ( $\mathrm{mi} / \mathrm{mi})$ mast cell-deficient mice. ${ }^{38}$ In addition, mast cell deficiency enhances nitric oxide synthase activity in mouse jejunum ${ }^{39}$ probably due to the lack of mast cell granule mediators that serve to inhibit nitric oxide production. ${ }^{40}$ Increasing evidence now indicates that interleukin-17 acts on bone marrow stroma cells by inducing the release of granulocyte colonystimulating factor (G-CSF) and $\mathrm{SCF}$, and $\mathrm{Sl} / \mathrm{Sl}^{\mathrm{d}}$ mice are capable of secreting G-CSF in response to interleukin-17. ${ }^{41}$ It is not known whether mice maintained on a high-fat diet had elevated levels of interleukin-17 that in turn induced the secretion of G-CSF. Bubnic et al. ${ }^{42}$ demonstrated correction of erythroid and mast cell deficiency in $\mathrm{Sl} / \mathrm{Sl}^{\mathrm{d}}$ mice by stromal cell infusion. However, they failed to correct for anemia in these animals. The present data demonstrating the correction of granulopoesis without the restoration of hemoglobin levels are in agreement with their finding. To our knowledge, this is the first evidence that demonstrates restoration of granulopoiesis and erythropoeisis by a high-fat diet. Taken together, the $\mathrm{Sl} / \mathrm{Sl}^{\mathrm{d}}$ mice demonstrate increased aortic intima media thickness, hypertriglyceridemia, anemia, mast cell deficiency and impaired granulopoeisis. The derangements in the vascular wall structure and lipid metabolism may be attributed to the collective deficiency of stem cell factor and mast cell proteases.

ACKNOWLEDGEMENTS. This work was supported by grants from the American Heart Association (9808405P), the Hinman Fund, and the Joseph and Elizabeth Carey Arthritis Funds from the Kansas University Endowment Association.

\section{References}

1. Davies MJ. The composition of coronary artery plaques. $N$ Engl J Med 1997; 336: $1312-1314$

2. Ross R. Atherosclerosis - an inflammatory disease. N Engl J Med 1999; 340: $115-126$

3. Galli SJ. New concepts about the mast cell. N Engl J Med 1993; 328: $257-265$.

4. Schwartz LB, Irani AM, Roller K, Castells MC, Schechter NM. Quantitation of histamine, tryptase and chymase in dispersed human $\mathrm{T}$ and $\mathrm{TC}$ mast cells. J Immunol 1987; 138: 2611-2615.

5. Reynolds DS, Gurley DS, Stevens RL, Sugarbaker DJ, Austen KF, Serafin WE. Cloning of cDNAs that encode human mast cell carboxypeptidase $\mathrm{A}$, and comparison of the protein with mouse mast cell carboxypeptidase A and rat pancreatic carboxypeptidases. Proc Natl Acad Sci USA 1989; 86: 9480-9484

6. Vanderslice P, Ballinger SM, Tam EK, Goldstein SM, Craik CS, Caughey GH. Human mast cell tryptase: multiple cDNAs and genes reveal a multigene serine protease family. Proc Natl Acad Sci USA 1990; 87: $3811-3815$.

7. Urata H, Kinoshita A, Misono KS, Bumpus PM, Husain A. Identification of a highly specific chymase as major angiotensin II forming enzyme in human heart. J Biol Chem 1990; 265: 22348-22357.

8. Fernex M. The Mast Cell System. Its Relationship to Atherosclerosis, Fibrosis and Eosinophils, Basel: Karger AG, 1968.

9. Kalsner S, Richards R. Coronary arteries of cardiac patients are hyper reactive and contain stores of amines: a mechanism for coronary spasm. Science 1984; 223: 1435-1437.

10. Forman MB, Oates JA, Robertson D, Robertson RM, Roberts LJ, Virman R. Increased adventitial mast cells in a patient with coronary spasm. $N$ Engl J Med 1985; 313: 1138-1141.

11. Dvorak AM. Mast cell degranulation in human hearts. N Engl J Med 1986 315: $969-970$.
12. Patella V, Marino I, Lambarter B, Arbustini E, Adt M, Marone G. Human heart mast cells: isolation, purification, ultrastructure and immunological characterization. J Immunol 1995; 154: 2855-2865.

13. Kokkonen JO, Lindstedt KA, Kovanen PT. Metabolism of LDL in mast cells recovering from degranulation. Description of a novel intracellular pathway leading to proteolytic modification of the lipoprotein. Arterioscler Thromb 1993; 13: 276-285.

14. Jeziorska M, McCollum C, Wooley DE. Mast cell distribution, activation, and phenotype in atherosclerotic lesions of human carotid arteries. $J$ Pathol 1997; 182: 115-122.

15. Jeziorska M, McCollum C, Wooley DE. Calcification in atherosclerotic plaque of human carotid arteries: associations with mast cells and macrophages. J Pathol 1998; 185: 10-17.

16. DeSchryver-Kecskemeti K, Williamson JR, Jakchik BA, Clouse RE, Alpers DH. Mast cell granules within endothelial cells as a possible signal in the inflammatory process. Modern Pathol 1992; 5: 343-347.

17. Marks RM, Roche WR, Czerniecki M, Penny R, Nelson DS. Mast cell granules cause proliferation of human microvascular endothelial cells. Lab Invest 1984; 55: 289-294.

18. Hoit BD, Shao Y, Kinoshita A, Gabel M, Husain A, Walsh RA. Effects of angiotensin II generated by an angiotensin converting enzyme-independent pathway on left ventricular performance in the conscious baboon. J Clin Invest 1995; 95: 1519-1527.

19. Lindstedt KA. Inhibition of macrophage-mediated low-density lipoprotein oxidation by stimulated rat serosal mast cells. J Biol Chem 1993; 268: $7741-7746$.

20. Flanagan JG, Chan DC, Leder P. Transmembrane form of the kit ligand growth factor is determined by alternative splicing and is missing in the Sld mutant. Cell 1991; 64: 1025-1035.

21. Brannan CI, Lyman ESD, Williams J, et al. Steel-Dickie mutation encodes a c-kit ligand lacking transmembrane and cytoplasmic domains. Proc Natl Acad Sci USA 1991; 88: 4671-4674.

22. Allain CC, Poon LS, Chan CS, Richmond W, Fu PC. Enzymatic determination of total serum cholesterol. Clin Chem 1974; 20: 470-475.

23. Bucolo G, David H. Quantitative determination of serum triglycerides by the use of enzymes. Clin Chem 1973; 19: 476-482.

24. Jehle AB, Stechschulte AC, Li Y, Stechschulte DJ, Dileepan KN. Endotoxin and mast cell granule proteases synergistically activate human coronary artery endothelial cells to generate interleukin- 6 and interleukin-8. J Interferon Cytokine Res 2000; 20: 361-368.

25. Li Y, Chi L, Stechschulte DJ, Dileepan KN. Histamine-induced production of interleukin- 6 and interleukin- 8 by human coronary artery endothelial cells is enhanced by endotoxin and tumor necrosis factora. Microvascular Res 2001; 61: 253-262.

26. Chi L, Li Y, Stehno-Bittel L, Gao J, Morrison DC, Stechschulte DJ, Dileepan KN. Interleukin-6 production by endothelial cells via protease activated receptor stimulation is synegized by endotoxin and tumor necrosis factor- $\alpha$. J Interferon Cytokine Res 2001; 21: 231-240.

27. Talreja J, Kabir MH, Filla M, Stechschulte DJ, Dileepan KN. Histamine enhances endothelial cell inflammatory responses to bacterial cell wall components via up-regulation of Toll-like receptors 2 and 4. Immunology 2004; 113: 224-233.

28. Baram D, Vaday GG, Salamon P, Drucker I, Hershkoviz R, Mekori YA. Human mast cells release metalloproteinase-9 on contact with activated T cells: juxtacrine regulation by TNF- $\alpha$. J Immunol 2001; 167: $4008-$ 4016.

29. Lohi J, Harvima I, Keski-Oja J. Pericellular substrates of human mast cell tryptase: 72,000 dalton gelatinase and fibronectin. J Cell Biochem 1992; 50: $337-349$.

30. Fang KC, Raymond WW, Lazarus SC, Caughey GH. Dog mastocytoma cells secrete a $92-\mathrm{kD}$ gelatinase activated extracellularly by mast cell chymase. J Clin Invest 1996; 97: 1589-1596.

31. Lees M, Taylor DJ, Woolley DE. Mast cell proteinases activate precursor forms of collagenase and stromelysin, but not of gelatinases A and B. Eur J Biochem 1994; 223: 171-177.

32. Fang KC, Wolters PJ, Steinhoff M, Bidgol A, Blount JL, Caughey GH. Mast cell expression of gelatinases A and B is regulated by kit ligand and TGFB. J Immunol 1999; 162: 5528-5535.

33. Tanaka A, Arai K, Kitamura Y, Matsuda H. Matrix metalloproteinase-9 production, a newly identified function of mast cell progenitors, is downregulated by c-kit receptor activation. Blood 1999; 94: 2390-2395.

34. Hatanaka K, Tanishita H, Ishibashi-Ueda H, Yamamoto A. Hyperlipidemia in mast cell-deficient $\mathrm{W} / \mathrm{W}^{\mathrm{V}}$ mice. Biochim Biophys Acta 1986; 878: $440-445$.

35. Ikemoto S, Takahashi M, Tsunoda N, et al . Cholate inhibits high-fat dietinduced hyperglycemia and obesity with acyl-CoA synthetase mRNA decrease. Am J Physiol 1997; 273: E37-E45.

36. Fleischman RA, Simpson F, Gallardo T, Jin XL, Perkins S. Isolation of endothelial-like stromal cells that express Kit ligand and support in vitro hematopoiesis. Exp Hematol 1995; 23: 1407-1416.

37. Flanagan JG, Leder P. The kit ligand: a cell surface molecule altered in steel mutant fibroblasts. Cell 1990; 63: 185-194.

38. Stechschulte DJ, Sharma R, Dileepan KN, Simpson KM, Aggarwal N, Clancy J, Jr, Jilka RL. The effect of mi allele on mast cells, basophils, natural killer cells and osteoclasts in mice. J Cell Physiol 1987; 132: $565-570$. 
39. Komatsu S, Grisham MB, Russell JM, Granger DN. Enhanced mucosal permeability and nitric oxide synthase activity in jejunum of mast cell deficient mice. Gut 1997; 41: 636-641.

40. Dileepan KN, Lorsbach RB, Stechschulte DJ. Mast cell granules inhibit macrophage-mediated lysis of mastocytoma cells (P815) and nitric oxide production. J Leuk Biol 1993; 53: 446-453.

41. Schwarzenberger P, Huang W, Ye P, et al. Requirement of endogenous stem cell factor and granulocyte-colony-stimulating factor for IL-17mediated granulopoiesis. J Immunol 2000; 164: 4783-4789.
42. Bubnic SJ, Wang X-H, Clark BR, Keating A. W/W $\mathrm{W}^{\mathrm{V}}$ marrow stromal cells engraft and enhance early erythropoietic progenitors in unconditioned sl/sld murine recipients. Bone Marrow Transplant 2002; 30: 867-872.

Received 5 July 2004

Accepted 5 August 2004 


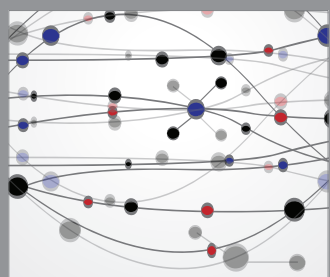

The Scientific World Journal
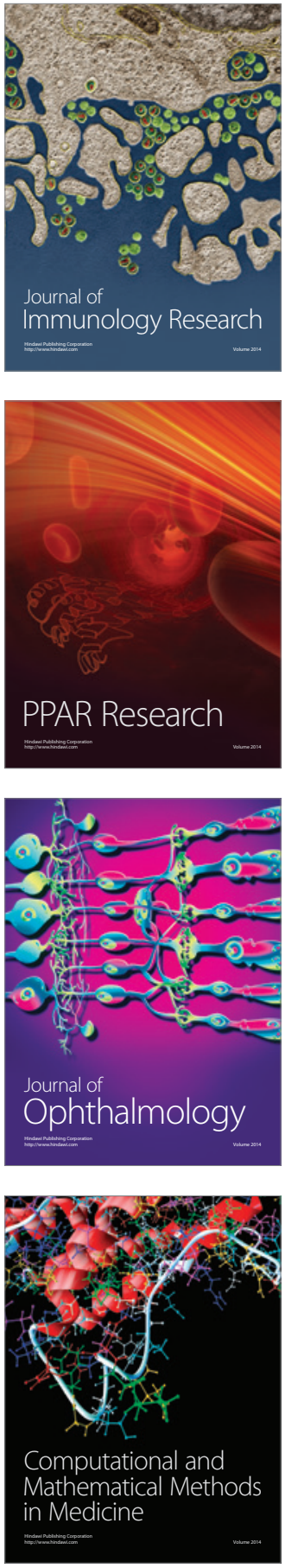

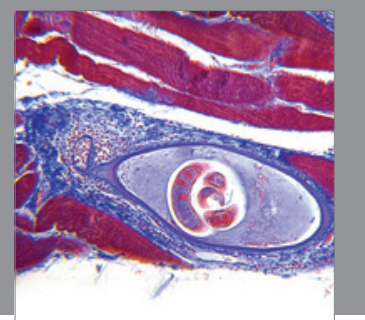

Gastroenterology

Research and Practice
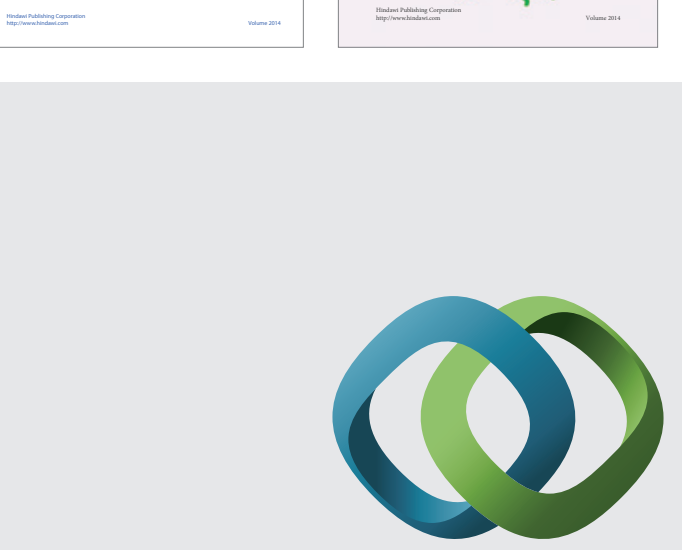

\section{Hindawi}

Submit your manuscripts at

http://www.hindawi.com
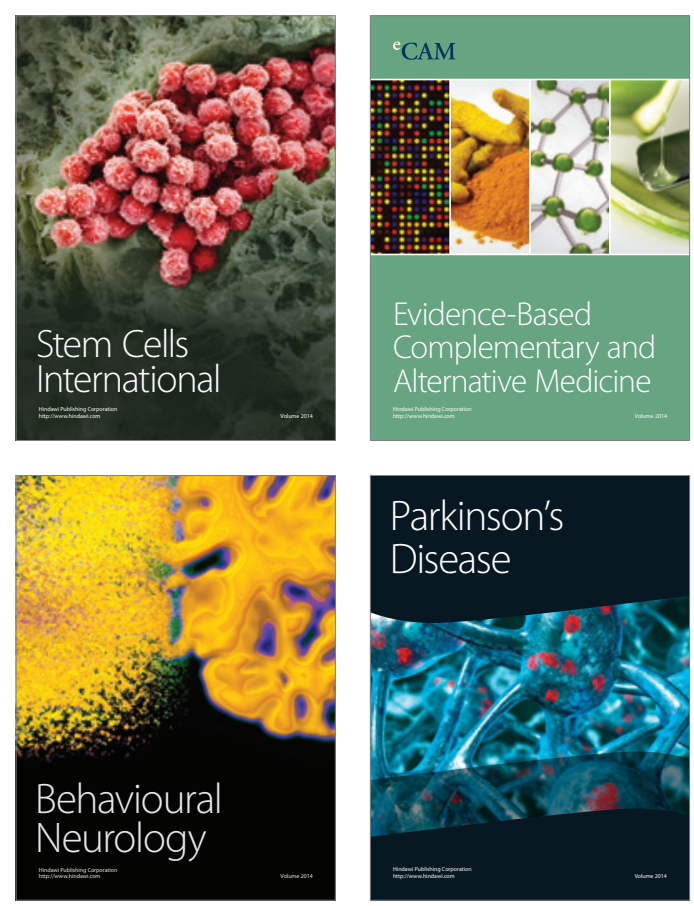

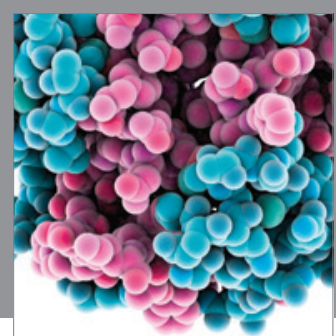

Journal of
Diabetes Research

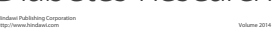

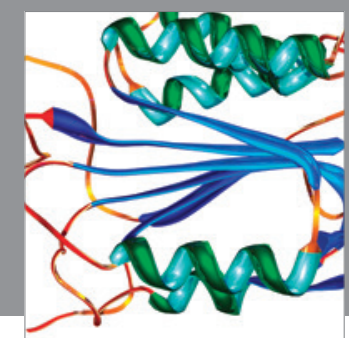

Disease Markers
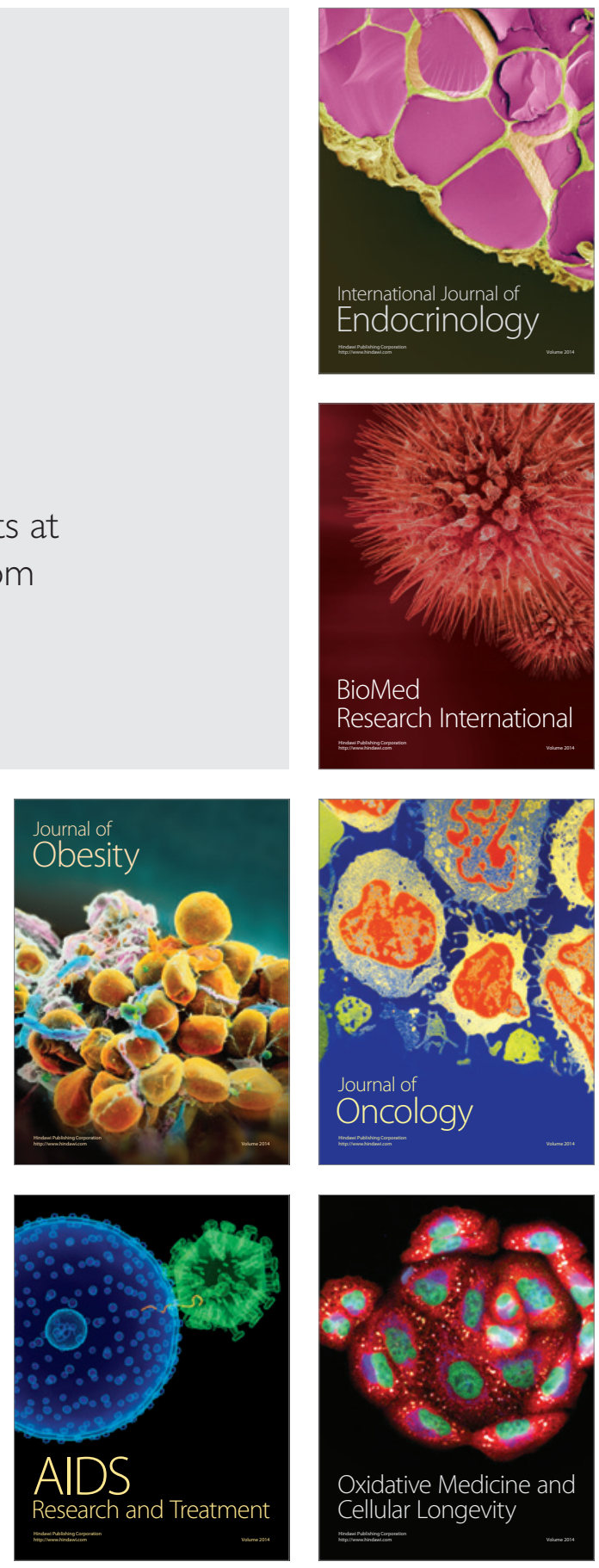